\title{
IMPLEMENTASI ALGORITMA SUBEXPONENTIAL CODE UNTUK KOMPRESI FILE GAMBAR
}

\author{
Amir Maniur Silitonga ${ }^{1}$, Surya Darma Nasution², Putri Ramadhani ${ }^{3}$ \\ Program Studi Teknik Informatika STMIK Budi Darma, Medan, Indonesia \\ Email: 19mirmaniur2@gmail.com, ${ }^{2}$ surya.darma.nasution1@gmail.com, ${ }^{3}$ pramadhaniput@gmail.com
}

\begin{abstract}
Abstrak
Ukuran File gambar terkadang relatif besar dimana semakin baik mutu gambar yang dihasilkan, maka bentuk pixel yang diperlukan buat merekam gambar tersebut tambah besar. Dengan ukuran file gambar yang sangat besar, pada saat melakukan proses pemindahan bisa saja proses pemindahan gagal karena media ruang penyimpanan melebihi batasnya.Adapun Solusi dalam permasalah ini adalah bagaimana file gambar tersebut dapat dikompresi guna untuk mempercepat pemindahan dan penyimpanan file gambar. kompresi pada file gambar dilakukan dengan memperkecil bentuk file gambar dengan proses mengurangi bit pada file gambar, akan tetapi tidak menghilangkan data informasi didalamnya.Dengan menjalankan kompresi, file yang besar akan mengecil ukurannya sehingga dapat mengirit ruang penyimpanan. Dalam penelitian ini, algoritma yang digunakan adalah Subexponential Code, dengan menggunakan metode tersebut, hasil kompresi dari nilai k mempunyai hasil yang berbeda-beda dari setiap nilai nya, dan hasil kompresi akan menguntungan dalam melakukan pengiriman, dan pemindahan file gambar akan semakin mudah.
\end{abstract}

Kata Kunci: kompresi file gambar,algoritma subexponential code

\begin{abstract}
Image file size is sometimes relatively large where the better the quality of the image produced, the pixel shape needed to record the image is bigger. With a very large image file size, at the time of the transfer process the transfer process could fail because the storage space media exceeds its limit. As for the Solution in this problem is how the image file can be compressed in order to accelerate the transfer and storage of image files. compression on image files is done by reducing the shape of the image file by reducing the bit in the image file, but does not eliminate the information data in it. By running compression, large files will shrink in size so that it can save storage space. In this study, the algorithm used is Subexponential Code, by using this method, the compression results from the $k$ value have different results from each value, and the compression results will be advantageous in sending, and transferring image files will be easier.
\end{abstract}

Keywords: image file compression, subexponential code algorithm

\section{PENDAHULUAN}

Umumnya kehidupan pada bidang teknologi informasi, pemindahan data atau sebuah informasi tersebut sangat sering dilakukan melalui media penyimpanan ataupun melalui suatu media seperti internet. Kecepatan pengiriman suatu data maupun informasi pada suatu bentuk yang bertipe file gambar akan menjadi bagian utama dalam pertukaran suatu informasi atau data dimasa yang akan datang. Besarnya suatu ukuran data yang akan dipindahkan, sangat dibutuhkan ruang penyimpanan yang cukup untuk suatu proses pemindahan, dan proses pemindahan bisa sajah gagal dilakukan jika ukuran file yang akan dipindahkan lebih besar dari ruang yang tersedia, dan salah satu teknik yang dibutuhkan untuk masalah tersebut adalah teknik kompresi. kompresi bermaksud untuk mengekecilkan bentuk file sehingga saat melakukan proses pemindahan atau dalam penyimpanan suatu file akan menjadi lebih mudah atau efisien.

Ukuran File gambar (citra) relatif besar dimana semakin bagus jenis gambar yang diperoleh, lalu bentuk pixel yang dibutuhkan guna merekam gambar tersebut lebih besar, proses kompresi adalah salah satu alternatip yang sangat dibutuhkan untuk memperkecil kapasitas suatu file gambar, agar tidak terlalu boros dalam menggunakan ruang penyimpanan. Dengan ukuran suatu data yang telah dilakukan proses pengecilan atau penguragan bit terhadap suatu file gambar, pada saat melakukan proses pemindahan atau pengiriman file gambar yang telah dilakukan pengurangan bit, maka proses pemindahan terhadap file akan semakin mudah dan cepat. karena media ruang penyimpanan memiliki ruang yang cukum untuk menampung file gambar yang telah dilakukannya pengurangan bit atau proses kompresi terhadap suatu file yang telah di pindahkan tersebut.

Dari perolehan penelitian sebelumnya yang di buat oleh Kharisma Mahesa dan Karpen pada tahun 2017 telah berhasil membuktikan bahwa mengkompresi citra digital menggunakan metode huffman dan dapat mengembalikan citra yang terkompresi kedalam bentuk semula dalam proses implementasi adalah citra digital dengan format Bitmap (*.bmp) dengan kedalaman warna 24bit[1].

Pada tahun 2017 Leni Marlina, Andysah Putera Utama Sihaan, Heri Kurniawan dan Indri Sulistianingsih telah berhasil membuktikan bahwa kompresi data yang dilakukan dengan menggunakan algoritma elias delta code sangat menghemat ruang media penyimpanan dan dapat memampatkan semua tipe data. Konsep kerja kompresi berdasarkan algoritma elias delta code dilakukan dengan mengubah nilai pixel citra, kemudian dengan memanfaatkan urutan kemunculan nilai-nilai pixel pada citra yang akan dikompresi[2].

Dengan hal tersebut penulis menggunakan algoritna Subexponential Code untuk mengetahui kinerja kompresi apabila dilakukan terhadap file gambar, sehingga file gambar yang berukuran besar akan dikompresi menjadi ukuran yang lebi kecil, dimana file gambar akan membutuhkan jangka pemindahan yang makin singkat dibandingkan pada file gambar yang bukan terkompresi serta memperkecil ruang alokasi penyimpanan data. 


\section{TEORITIS}

\subsection{Kompresi Data}

File kompresi dimaksudkan sebagai data yang digabungkan merupakan satu dengan makna untuk memperoleh ukuran data yang kian kecil dibandingkan pada data aslinya. Data yang dikompresi memungkinkan file lebih cepat ketika di-download dan lebih banyak data yang tersimpan dalam media penyimpanan eksternal[3]. Terdapat dua teknik yang dapat dilakukan pada saat melakukan kompresi[4]:

\subsection{Rasio Kompresi (Compression Ratio)}

Rasio kompresi adalah menghitung kinerja dari repersentase data yang sudah dikompresi dan sebelum dikompresi[5]. Secara matematis rasio pemanpatan data dituliskan sebagai berikut.

$$
\text { Rasio }=100 \%-\left[\frac{\text { hasil kompresi }}{\text { data asli }} \times 100 \%\right]
$$

Misalkan rasio kompresi adalah $10 \%$ artinya $10 \%$ dari data semulah telah berhasil dimampatkan.

\subsection{Dekompresi}

Dekompresi merupakan proses mengembalikan sebuah data yang sudah terkompresi. Sebuah data yang telah dikompres tentunyaharus bisa dikembalikan juga kebentuk aslinya. Untuk mampu merubah data yang terkompres dibutuhkan cara yang berlainan seperti dalam waktu proses kompres dilaksanakan. Jadi pada waktu dekompres terdapat catatan header yang berbentuk byte-byte yang mengandung catatan akan isi dari data tersebut[6].

\subsection{Algoritma Subexponential Code}

Subexponential Code merupakan algoritma yang menghasilkan bit tertentu yang merupakan kode tidak relevan. Mengingat satu set kode yang memiliki sifat-sifat yang diinginkan[7]. Pada Algoritma Subexponential Code tidak memeriksa bit satu persatu dari kode dan objek jika ada kelangkaan 0 atau terlalu sedikit 1 . Namun, mungkin ada aplikasi di mana hal ini menguntungkan untuk memiliki kode yang memulai atau mengakhiri dengan cara yang khusus, seperti pada Algoritma Subexponential Code ini, yang menyajikan kode awalan yang berakhir dengan 1[8].

Beberapa cara untuk membangun kode tersebut dan membuktikan, berikut ini batas pada panjang rata-rata mereka. suatu nilai k yang maksudnya adalah sangat banyaknya angka 1 pada suffix dari kode terkompresi. Pada mode encode, dibuat pemisahan bagi prefix dan suffix. Saat mode decode, decoder membaca sign bit dan loncat ke angka 0 pertama berawal bagian kiri, yang mana bakal berlanjut kembali oleh penambahan bit pada k berikutnya [8].

Tabel 1. Tabel Kode k Subexponential Code

\begin{tabular}{ccccccc}
\hline$N$ & $k=0$ & $k=1$ & $k=2$ & $k=3$ & $k=4$ & $k=5$ \\
\hline 0 & $0 \mid$ & $0 \mid 0$ & $0 \mid 00$ & $0 \mid 000$ & $0 \mid 0000$ & $0 \mid 00000$ \\
1 & $10 \mid$ & $0 \mid 1$ & $0 \mid 01$ & $0 \mid 001$ & $0 \mid 0001$ & $0 \mid 00001$ \\
2 & $110 \mid 0$ & $10 \mid 0$ & $0 \mid 10$ & $0 \mid 010$ & $0 \mid 0010$ & $0 \mid 00010$ \\
3 & $110 \mid 1$ & $10 \mid 1$ & $0 \mid 11$ & $0 \mid 011$ & $0 \mid 0011$ & $0 \mid 00011$ \\
4 & $1110 \mid 00$ & $110 \mid 00$ & $10 \mid 00$ & $0 \mid 100$ & $0 \mid 0100$ & $0 \mid 00100$ \\
5 & $1110 \mid 01$ & $110 \mid 01$ & $10 \mid 01$ & $0 \mid 101$ & $0 \mid 0101$ & $0 \mid 00101$ \\
6 & $1110 \mid 10$ & $110 \mid 10$ & $10 \mid 10$ & $0 \mid 110$ & $0 \mid 0110$ & $0 \mid 00110$ \\
7 & $1110 \mid 11$ & $110 \mid 11$ & $10 \mid 11$ & $0 \mid 111$ & $0 \mid 0111$ & $0 \mid 00111$ \\
8 & $11110 \mid 000$ & $1110 \mid 000$ & $110 \mid 000$ & $10 \mid 000$ & $0 \mid 1000$ & $0 \mid 01000$ \\
9 & $11110 \mid 001$ & $1110 \mid 001$ & $110 \mid 001$ & $10 \mid 001$ & $0 \mid 1001$ & $0 \mid 01001$ \\
10 & $11110 \mid 010$ & $1110 \mid 010$ & $110 \mid 010$ & $10 \mid 010$ & $0 \mid 1010$ & $0 \mid 01010$ \\
11 & $11110 \mid 011$ & $1110 \mid 011$ & $110 \mid 011$ & $10 \mid 011$ & $0 \mid 1011$ & $0 \mid 01011$ \\
12 & $11110 \mid 100$ & $1110 \mid 100$ & $110 \mid 100$ & $10 \mid 100$ & $0 \mid 1100$ & $0 \mid 01100$ \\
13 & $11110 \mid 101$ & $1110 \mid 101$ & $110 \mid 101$ & $10 \mid 101$ & $0 \mid 1101$ & $0 \mid 01101$ \\
14 & $11110 \mid 110$ & $1110 \mid 110$ & $110 \mid 110$ & $10 \mid 110$ & $0 \mid 1110$ & $0 \mid 01110$ \\
15 & $11110 \mid 111$ & $1110 \mid 111$ & $110 \mid 111$ & $10 \mid 111$ & $0 \mid 1111$ & $0 \mid 01111$ \\
16 & $111110 \mid 0000$ & $11110 \mid 0000$ & $1110 \mid 0000$ & $110 \mid 0000$ & $10 \mid 0000$ & $0 \mid 10000$ \\
\hline
\end{tabular}

Sumber: David salomon Giovanni Motta 2010[8]

\subsection{Citra}

Citra atau gambar merupakan cara yang orang pakai guna menyampaikan pesan terhadap orang yang berbeda. Citra merupakan kombinasi antara titik, garis, bidang, dan warna untuk menghasilkan suatu tiruan dan suatu benda seperti, benda wujud atau benda mahluk [9].

\section{ANALISA DAN PEMBAHASAN}

\subsection{Analisa}


Gambar adalah suatu media yang terkadang digunakan saat berkomunikasi dan digunakan sebagai alat pengungkapan, ilustrasi, ingatan (memorize) dan lain sebagainya. Masalah yang sering terjadi adalah terkadang ukuran gambar yang dihasilkan semakin besar, maka jumlah pixel yang dibutuhkan untuk proses pemindahan semakin lama, dan membutuhkan alokasi penyimpanan yang besar, sehingga sebagian banyak orang merasa terganggu dalam proses penyimpanan karena banyak memakan ruang dari penyimpanan yang disediakan, penelitian ini, bertujuan untuk melakukan analisa dari cara kerja dalam perancangan perangkat lunak pengkompresian file gambar dengan menggunakan algoritma subexponential code.

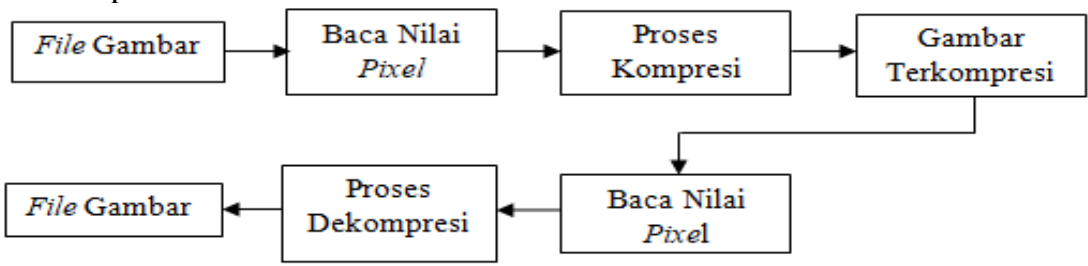

Gambar 1. Prosedur Kompresi Dekompresi File Gambar

Berdasarkan gambar yang ada diatas masukan pertama adalah file gambar yang belum dilakukannya proses kompresi. keluaran dari hasil kompresi adalah sebuah file gambar yang ukurannya telah diubah dari kapasitas awal. Proses dekompresi adalah proses yang mengembalikan kapasitas awal dari file gambar sebelumnya.

1. Analisa terhadap proses kompresi file gambar dengan menggunakan subexponential code langkah pertama dalam melakukan kompresi file gambar adalah dengan memasukkan file gambar yang akan dikompresi yaitu gambar yang berukuran 960 x 1280 pixel.

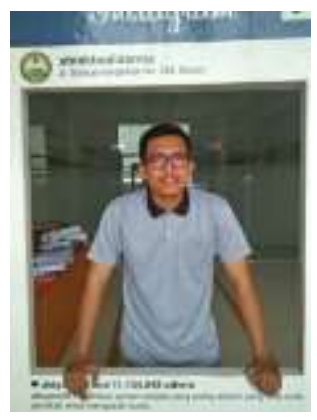

Gambar 2. Citra Asli

Berdasarkan dari gambar 3.2 yang di atas akan diambil sempel gambar untuk keperluan hitung manual menggunakan metode subexponential code. Resolusi yang akan diambil adalah 5 x 5 pixel. Gambar sempel tersebut akan diambil nilai desimal dengan cara mengektraksi elemen nilai setiap pixel.

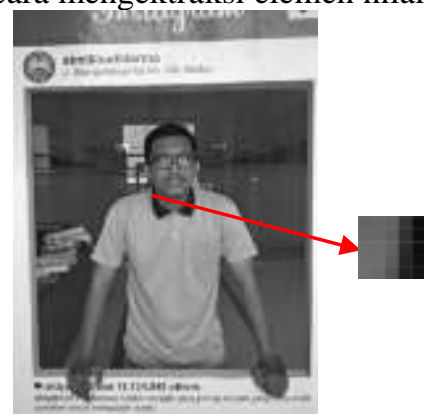

Gambar 3. Sempel Gambar

Berdasarkan proses analisa yang dilakukan diambil sample gambar sebesar 5 x 5 pixel dengan kedalaman warna 24 bit. Proses kompresi yang akan dilakukan menggunakan algoritma Subexponential code untuk kompresi file gambar. Dengan begitu dapat dihitung $5 \times 5 \times 24$ bit $=600$ bit. Apabila diubah kedalam satuan bytes menjadi $600 / 8=75$ bytes. Berikut sampel gambar yang akan dikompresi.

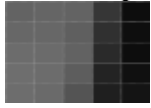

Gambar 4. Sempel Gambar 5 x 5 Pixel

Langkah selanjutnya adalah dengan melakukan pembacaan isi file gambar. Didalam file gambar terdapat nilai pixel. Nilai pixel diambil dalam bentuk 5 x 5 sehingga menghasilkan 25 pixel sebagai sampel gambar yang akan dianalisa. Nilai pixel yang akan dianalisa dapat dilihat di gambar 3.5: 


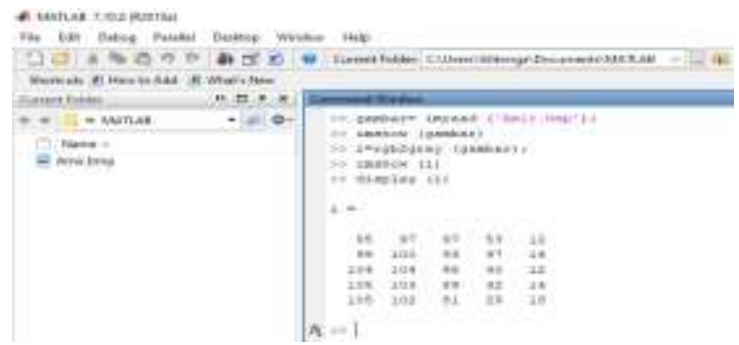

Gambar 5. Nilai 25 Pixel Sempel

Berdasarkan dari gambar 3.5 maka didapatkan nilai pixel karakter sebagai berikut, 95, 97, 97, 53, 12, 99, 100, 93, $47,14,104,104,95,40,12,105,103,89,32,14,105,102,81,29,18$. Nilai pixel yang didapat dimasukkan kedalam table, dan mencari nilai pixel yang sama untuk dilakukan pembacaan total frekuensi. Adapun pencarian nilai pixel yang sama, dan pembacaan total frekuensi bisa dilihat dalam tabel di bawah ini:

Tabel 2 Pembacaan Nilai Pixel

\begin{tabular}{cc}
\hline Pixel & Frekuensi \\
\hline 95 & 2 \\
97 & 2 \\
53 & 1 \\
12 & 2 \\
99 & 1 \\
100 & 1 \\
93 & 1 \\
47 & 1 \\
14 & 2 \\
104 & 2 \\
40 & 1 \\
105 & 2 \\
103 & 1 \\
89 & 1 \\
32 & 1 \\
102 & 1 \\
81 & 1 \\
29 & 1 \\
18 & 1 \\
Total & 25 \\
Pixel & \\
\hline
\end{tabular}

Berdasarkan pada tabel 2, terdapat beberapa nilai pixel yang sama. Sebelum proses kompresi citra, langkah awal adalah membaca nilai pixel citra kemudian membuat tabel nilai pixel yang diurutkan dari nilai frekuensi terbesar (nilai yang sama) hingga ke terkecil. Urutan nilai pixel bisa dilihat dalam tabel di bawah ini:

Tabel 3. Pixel yang Belum Dikompresi

\begin{tabular}{ccccc}
\hline Nilai Pixel & Binary & Bit & Frek & Bit x Frek \\
\hline 95 & 01011111 & 8 & 2 & 16 \\
97 & 01100001 & 8 & 2 & 16 \\
12 & 00001100 & 8 & 2 & 16 \\
14 & 00001110 & 8 & 2 & 16 \\
104 & 01101000 & 8 & 2 & 16 \\
105 & 01101001 & 8 & 2 & 16 \\
53 & 00110101 & 8 & 1 & 8 \\
99 & 01100011 & 8 & 1 & 8 \\
100 & 01100100 & 8 & 1 & 8 \\
93 & 01011101 & 8 & 1 & 8 \\
47 & 00101111 & 8 & 1 & 8 \\
40 & 00101000 & 8 & 1 & 8 \\
103 & 01100111 & 8 & 1 & 8 \\
89 & 01011001 & 8 & 1 & 8 \\
32 & 00100000 & 8 & 1 & 8 \\
102 & 01100110 & 8 & 1 & 8 \\
81 & 01010001 & 8 & 1 & 8 \\
29 & 00011101 & 8 & 1 & 8 \\
18 & 00010010 & 8 & 1 & 8 \\
& Total Bit & & & 200 \\
\hline
\end{tabular}


Langaka selanjutnya adalah dengan melihat tabel 1 algoritma subexponential code yang ada diatas, hanya menunjukkan nilai kode algoritma sampai karakter ke 16. Bagaimana jika jumlah karakter yang dihasilkan lebih dari 16 karakter. Didalam metode subexponential code, seatu nilai k yang maksudnya adalah banyaknya nilai 1 dalam suffix atas kode terkompresi. Pada proses encode, dilakukan pemisahan angka 1 pada suffix dari kode terkompresi. Dalam proses encode, di buat pemisah bagi prefix dan suffix. Saat proses decode, decoder membaca sign bit dan loncat ke angka 0 pertama dari sisi kiri, yang mana bakal berlanjut kembali untuk penambahan bit atas $\mathrm{k}$ selanjutnya. untuk nilai k dalam proses kompresi memakai subexponential code bisa dilihat dalam tabel 5 berikut ini.

Tabel 4. Tambahan Codeword Subexponential Code

\begin{tabular}{rrrrrrrrrrrrl}
\hline$N$ & $k$ & \multicolumn{2}{c}{$k=1$} & \multicolumn{2}{c}{$k=2$} & $k=3$ & $k=4$ & $k=5$ \\
\hline 0 & 0 & & 0 & 0 & 0 & 00 & 0 & 000 & 0 & 0000 & 0 & 00000 \\
1 & 10 & 0 & 1 & 0 & 01 & 0 & 001 & 0 & 0001 & 0 & 00001 \\
2 & 110 & 0 & 10 & 0 & 0 & 10 & 0 & 010 & 0 & 0010 & 0 & 00010 \\
3 & 110 & 1 & 10 & 1 & 0 & 11 & 0 & 011 & 0 & 0011 & 0 & 00011 \\
4 & 1110 & 00 & 110 & 00 & 10 & 00 & 0 & 100 & 0 & 0100 & 0 & 00100 \\
5 & 1110 & 01 & 110 & 01 & 10 & 01 & 0 & 101 & 0 & 0101 & 0 & 00101 \\
6 & 1110 & 10 & 110 & 10 & 10 & 10 & 0 & 110 & 0 & 0110 & 0 & 00110 \\
7 & 1110 & 11 & 110 & 11 & 10 & 11 & 0 & 111 & 0 & 0111 & 0 & 00111 \\
8 & 11110 & 000 & 1110 & 000 & 110 & 000 & 10 & 000 & 0 & 1000 & 0 & 01000 \\
9 & 11110 & 001 & 1110 & 001 & 110 & 001 & 10 & 001 & 0 & 1001 & 0 & 01001 \\
10 & 11110 & 010 & 1110 & 010 & 110 & 010 & 10 & 010 & 0 & 1010 & 0 & 01010 \\
11 & 11110 & 011 & 1110 & 011 & 110 & 011 & 10 & 011 & 0 & 1011 & 0 & 01011 \\
12 & 11110 & 100 & 1110 & 100 & 110 & 100 & 10 & 100 & 0 & 1100 & 0 & 01100 \\
13 & 11110 & 101 & 1110 & 101 & 110 & 101 & 10 & 101 & 0 & 1101 & 0 & 01101 \\
14 & 11110 & 110 & 1110 & 110 & 110 & 110 & 10 & 110 & 0 & 1110 & 0 & 01110 \\
15 & 11110 & 111 & 1110 & 111 & 110 & 111 & 10 & 111 & 0 & 1111 & 0 & 01111 \\
16 & 111110 & 0000 & 11110 & 0000 & 1110 & 0000 & 110 & 0000 & 10 & 0000 & 0 & 10000 \\
17 & 111110 & 0001 & 11110 & 0001 & 1110 & 0001 & 110 & 0001 & 10 & 0001 & 0 & 10001 \\
18 & 111110 & 0010 & 11110 & 0010 & 1110 & 0010 & 110 & 0010 & 10 & 0010 & 0 & 10010 \\
19 & 111110 & 0011 & 11110 & 0011 & 1110 & 0011 & 110 & 0011 & 10 & 0011 & 0 & 10011 \\
\hline
\end{tabular}

Langkah selanjutnya adalah melakukan kompresi nilai dari citra pixel sampel dengan nilai kode subexponential code yang telah didapatkan dari tabel 5, metode ini yang selalu diumpamakan dengan nilai $\mathrm{n}=1,2,3$, dst. Kemudian pilih nilai k dari 0 - 5 pada tabel 5 yang ada diatas. Adapun proses kompresi citra sempel menggunakan subexponential code sebagai berikut:

Untuk nilai $\mathrm{k}=0$

Tabel 5. Tabel Total Bit Setelah Dikompresi Menggunakan Subexponential Code Untuk Nilai k $=0$

\begin{tabular}{cccccc}
\hline N & $\begin{array}{c}\text { Nilai des } \\
\text { Pixel }\end{array}$ & $\begin{array}{c}\text { Subexponential } \\
\text { code }\end{array}$ & Bit & Frek & Bit x Frek \\
\hline 1 & 95 & 10 & 2 & 2 & 4 \\
2 & 97 & 1100 & 4 & 2 & 8 \\
3 & 12 & 1101 & 4 & 2 & 8 \\
4 & 14 & 111000 & 6 & 2 & 12 \\
5 & 104 & 111001 & 6 & 2 & 12 \\
6 & 105 & 111010 & 6 & 2 & 12 \\
7 & 53 & 111011 & 6 & 1 & 6 \\
8 & 99 & 11110000 & 8 & 1 & 8 \\
9 & 100 & 11110001 & 8 & 1 & 8 \\
10 & 93 & 11110010 & 8 & 1 & 8 \\
11 & 47 & 11110011 & 8 & 1 & 8 \\
12 & 40 & 11110100 & 8 & 1 & 8 \\
13 & 103 & 11110101 & 8 & 1 & 8 \\
14 & 89 & 11110110 & 8 & 1 & 8 \\
15 & 32 & 11110111 & 8 & 1 & 8 \\
16 & 102 & 1111100000 & 10 & 1 & 10 \\
17 & 81 & 1111100001 & 10 & 1 & 10 \\
18 & 29 & 1111100010 & 10 & 1 & 10 \\
19 & 18 & 1111100011 & 10 & 1 & 10 \\
& & Total Bit & & & 166 \\
\hline
\end{tabular}

Berdasarkan dari tabel 6 dapat dibentuk nilai bit baru hasil kompresi dari susunan nilai desimal pixel citra sempel awal sebelum di kompresi yaitu, 95, 97, 97, 53, 12, 99, 100, 93, 47, 14, 104, 104, 95, 40, 12, 105, 103, 89, 32, 14, 105, 102, 81, 29, 18 (tanpa tanda koma dan spasi) menjadi nilai bit biner 
“1011001100111011110111110000111100011111001011110011111000111001111001101111010011011110101111 $010111110110111101111110001110101111100000111110000111111000101111100011 ”$.

Sebelum di dapatkan hasil akhir kompresi dilakukan penambahan string bit itu sendiri yaitu padding bit dan flag bit. Penambahan bit (padding) dilakukan jika hasil kompresi dibagi 8 memiliki sisa. Sedangkan hasil kompresi tidak memiliki sisa atau nol maka tidak perlu adanya penambahan bit (padding). Sedangkan flag bit adalah nilai biner yang didapat dari nilai hasil padding. Flag bit memiliki jumlah nilai 8 bit biner. Berdasarkan hasil kompresi nilai pixel citra sampel menggunakan algoritma subexponential code di dapat nilai string bit sebanyak 166 bit dimana jika bilangan tersebut dibagi 8, maka akan menghasilkan sisa bagi sebanyak enam digit. Maka diperoleh padding 00.

“1011001100111011110111110000111100011111001011110011111000111001111001101111010011011110101111 01011111011011110111111000111010111110000011111000011111100010111110001100”

Dengan penambahan padding sebanyak dua bit, maka diperole flag 00000010. Maka diperoleh string bit baru sebagai berikut.

10110011001110111101111100001111000111110010111100111110001110011110011011110100110111101011110 101111101101111011111100011101011111000001111100001111110001011111000110000000010.

Maka, jumlah Total panjang bit keseluruhan setelah ada penambahan padding bit dan flag bit adalah $166+2$ $+8=176$. Selanjutnya lakukan pemisahan bit menjadi sejumlah kelompok. per kelompok terdiri dari 8 bit seperti gambar di bawah ini.

\begin{tabular}{|lllll|}
\hline 10110011 & 00111011 & 11011111 & 00001111 & 00011111 \\
00101111 & 00111110 & 00111001 & 11100110 & 11110100 \\
11011110 & 10111101 & 01111101 & 10111101 & 11111000 \\
11101011 & 11100000 & 11111000 & 011111110 & 00101111 \\
10001100 & 00000010 & & & \\
\hline
\end{tabular}

Gambar 6. Pembagian String Bit k=0

Maka, jumlah Total panjang bit keseluruhan setelah ada penambahan padding bit dan flag bit dari semua nilai algoritma subexponential code yang di namakan $\mathrm{k}=0-\mathrm{k}=5$ terkumpullah hasil kompresi nilai bit yang berbeda beda. adapun nilai k 0-5 hasil kompresi bisat dilihat dalam tabel dibawah ini:

Tabel 6. keseluruhan hasil kompresi nilai $\mathrm{k}=0$ sampai $\mathrm{k}=5$

\begin{tabular}{ccccccc}
\hline Nilai & $\mathrm{k}=0$ & $\mathrm{k}=1$ & $\mathrm{k}=2$ & $\mathrm{k}=3$ & $\mathrm{k}=4$ & $\mathrm{k}=5$ \\
\hline Total Bits & 176 & 152 & 136 & 120 & 144 & 160 \\
\hline
\end{tabular}

Berdasarkan pada pembagian kelompok nilai biner yang di dapat dari setiap nilai $\mathrm{k}=0$-5, didapatkan nilai $\mathrm{k}$ mempunyai kelompok nilai biner baru yang sudah terkompresi beserta nilai biner penambahan bit. Setelah pembagian dari nilai $\mathrm{k}=0$ sampai $\mathrm{k}=5$ yang dilakukan, maka pixel yang sudah dibagi kemudian diubah ke nilai desimal dari string bit nilai k yang dibagi menggunakan kode ASCII untuk mengetahui nilai dari pixel yang sudah terkompresi. Adapun nilai pixel yang sudah didapat dari nilai $\mathrm{k}=0-5$ yang sudah terkompresi dapat dilihat pada tabel sebagi berikut:

Nilai $k=0$

Tabel 7 Pengubahan Nilai Biner Ke Decimal Nilai k=0

\begin{tabular}{ccc}
\hline $\begin{array}{c}\text { Urutan Pixel } \\
\text { Terkompresi (n) }\end{array}$ & Nilai Biner & Nilai Des \\
\hline 1 & 10110011 & 179 \\
2 & 00111011 & 59 \\
3 & 11011111 & 223 \\
4 & 00001111 & 15 \\
5 & 00011111 & 31 \\
6 & 00101111 & 47 \\
7 & 00111110 & 62 \\
8 & 00111001 & 57 \\
9 & 11100110 & 230 \\
10 & 11110100 & 244 \\
11 & 11011110 & 222 \\
12 & 10111101 & 189 \\
13 & 01111101 & 125 \\
14 & 10111101 & 189 \\
15 & 11111000 & 248 \\
16 & 11101011 & 235 \\
17 & 11100000 & 224 \\
18 & 11111000 & 248 \\
19 & 01111110 & 126 \\
20 & 00101111 & 47 \\
21 & 10001100 & 140 \\
22 & 00000010 & 2 \\
\hline
\end{tabular}


Setelah nilai desimal diketahui, maka nilai akan di ubah menjadi suatu karakter. Karakter hasil dari proses kompresi yang dihasilkan, disimpan dalam suatu file dengan ekstensi ".spc", apabila file tersebut dibuka dengan aplikasi notepad, maka akan muncul karaktar sebagai gambar di bawah ini :

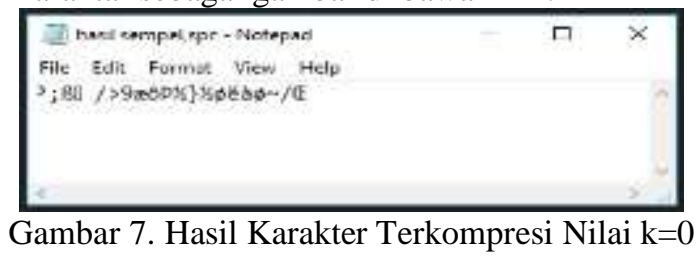

Agar pada saat di dekompresi dapat diketahui bahwa dimensi dari sempel gambar awal adalah 5 x 5 pixel, maka akan ditambahkan string ",2,0" pada karakter hasil dari kompresi. Karakter koma (,) yang pertama untuk memisahkan karakter hasil kompresi dengan karakter dimensi. Karakter dua "2" adalah nilai dari sumbu x yang terdapat pada gambar awal. Karakter koma (,) yang kedua untuk memisahkan nilai dari sumbuh x dengan nilai sumbuh y pada gambar awal. Karakter "0" adalah nilai dari sumbu y yang terdapat pada gambar. Sehingga didapatkan hasil kompresi citra setelah adanya penambahan string dimensi gambar ",2,0" (tanpa tanda petik) sebagai beriku:

\begin{tabular}{|c|c|}
\hline 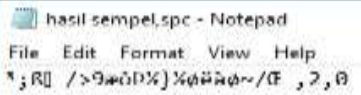 & $-\square$ \\
\hline
\end{tabular}

Gambar 8. Hasil kompresi Nilai k=0 Dengan Penambahan Dimensi Citra

Dari hasil kompresi dengan nilai $\mathrm{k}=0$ sampai dengan $\mathrm{k}=5$ diatas dapat dihitung kinerja dari metode tersebut, menggunakan Compression Ratio (CR) yaitu:

Untuk Nilai $\mathrm{k}=0$

Compression Ratio (CR)

$$
\begin{aligned}
C_{R} & =\frac{\text { Ukuran Data Setelah Dikompresi }}{\text { Ukuran Data Sebelum Dikompresi }} \times 100 \% \\
C_{R} & =\frac{176}{200} \times 100 \% \\
C_{R} & =88 \%
\end{aligned}
$$

2. Analisa proses dekompresi file gambar dengan menggunakan subexponential code.

Pada proses dekompresi yang dilakukan adalah menganalisa keseluruhan karakter aneh dari nilai $\mathrm{k}=0-5$ yang terkompresi sebelumnya. Berdasarkan dari hasil kompresi nilai $\mathrm{k}=0-5$ dengan adanya penambahan string dimensi biner didapati seperti gambar di bawah ini :

Untuk Nilai k=0



Gambar 9 Hasil Kompresi k=0

proses dekompresi yang pertama dilakukan mencari informasi dimensi dari gambar awal dengan menganbil karakter yang terdapat pada file hasil kompresi dimulai dari karakter yang diakhir sampai ketemu karakter koma (,) sebanyak dua kali. Karakter yang pertama diakhiri isi file hasil kompresi yaitu "0" menandakan itu adalah sumbu y pada gambar awal. Karakter yang kedua terdapat isi file hasil kompresi yaitu koma (,) yang pertama dimana karakter tersebut merupakan karakter pemisah antara sumbuh $\mathrm{x}$ dengan sumbuh y pada gambar awal. Karakter yang ketiga diakhir isi file hasil kompresi yaitu "2" yang menandakan itu adalah sumbuh x pada gambar awal. Karakter keempat adalah karakter koma (,) yang kedua dimana karakter tersebut merupakan pemisah antara dimensi gambar awal dengan string hasil kompresi. karena sudah terdapat dua karakter koma (,) maka informasi mengenai ukuran gambar awal sudah diketahui yaitu 5x5 pixel. Setelah dikenali dimensi gambar dari proses pengenalan nilai biner di atas maka nilai karakter dimensi gambar tersebut dihilangkan. Langkah selanjutnya mengubah hasil kompresi menjadi string bit awal, bisa dilihat pada gambar di bawah ini :

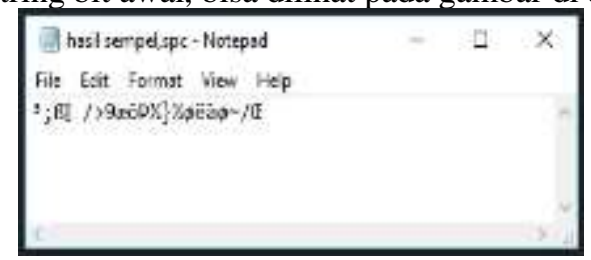


Gambar 10 Hasil Karakter Gambar k=0 Yang Akan Didekompresi

Selanjutnya proses dekompresi hal yang dilakukan adalah menganalisa keseluruhan bit hasil dari kompresi yang terdafat pada nilai $\mathrm{k}=0$ sebelumnya. Adapun bit keseluruhan hasil kompresi bisa dilihat dalam tabel berikut :

Tabel 8 Nilai Desimal dan Biner Pixel Kompresi

\begin{tabular}{ccc}
\hline Urutan Pixel Terkompresi (n) & Nilai Des & Nilai Biner \\
\hline 1 & 179 & 10110011 \\
2 & 59 & 00111011 \\
3 & 223 & 11011111 \\
4 & 15 & 0000111 \\
5 & 31 & 00011111 \\
6 & 47 & 00101111 \\
7 & 62 & 00111110 \\
8 & 57 & 00111001 \\
9 & 230 & 11100110 \\
10 & 244 & 11110100 \\
11 & 222 & 11011110 \\
12 & 189 & 10111101 \\
13 & 125 & 01111101 \\
14 & 189 & 10111101 \\
15 & 248 & 11111000 \\
16 & 235 & 11101011 \\
17 & 224 & 11100000 \\
18 & 248 & 11111000 \\
19 & 126 & 01111110 \\
20 & 47 & 00101111 \\
21 & 140 & 10001100 \\
22 & 2 & 00000010 \\
\hline
\end{tabular}

Berdasarkan pada tabel di atas maka diambil keseluruan nilai biner dan digabungkan seperti berikut ini:

“1011001100111011110111110000111100011111001011110011111000111001111001101111010011011110101 $1110101111101101111011111100011101011111000001111100001111110001011111000110000000010 ”$

1) Tahap Pertama

Proses pertama dekompresi adalah membaca nilai flag bits dari keseluruhan nilai bit tersebut dengan cara mengubah nilai 8 bit terakhir kedalam nilai desimal seperti di bawah ini:

10110011001110111101111100001111000111110010111100111110001110011110011011110100110111101 011110101111101101111011111100011101011111000001111100001111110001011111000110000000010 Didapatkan nilai 8 bit terakhir sebagai berikut, 00000010 dalam desimal adalah merupakan nilai 2. Nilai 2 tersebut menandakan bahwa hasil kompresi sebelumnya habis dibagi 8 sehingga ada penambahan padding dan flag bits. selanjutnya hapus padding dan flag bit dari nilai keseluruhan bit sehingga menjadi seperti di bawah ini:

10110011001110111101111100001111000111110010111100111110001110011110011011110100110111101 01111010111110110111101111110001110101111100000111110000111111000101111100011

2) Pengecekan Bit

Selanjutnya adalah melakukan pengecekan nilai bit, dari bit pertama dengan subexponential code pada tabel 6 di atas. jika ditemukan bit yang sesuai denan tabel nilai $\mathrm{k}=0$ di atas lalu ubah string yang benar. sehingga didapat hasil sesuai tabel di bawah ini:

Tabel 9 Dekompresi Nilai Pixel Citra Sampel

\begin{tabular}{ccc}
\hline $\mathrm{N}$ & Subexponential code & Nilai des Pixel \\
\hline 1 & 10 & 95 \\
2 & 1100 & 97 \\
3 & 1100 & 97 \\
4 & 111011 & 53 \\
5 & 1101 & 12 \\
6 & 11110000 & 99 \\
7 & 11110001 & 100 \\
8 & 11110010 & 93 \\
9 & 11110011 & 47 \\
10 & 111000 & 14 \\
11 & 111001 & 104 \\
12 & 111001 & 104 \\
13 & 10 & 95 \\
14 & 11110100 & 40
\end{tabular}




\begin{tabular}{ccc}
15 & 1101 & 12 \\
16 & 111010 & 105 \\
17 & 11110101 & 103 \\
18 & 11110110 & 89 \\
19 & 11110111 & 32 \\
20 & 111000 & 14 \\
21 & 111010 & 105 \\
22 & 1111100000 & 102 \\
23 & 1111100001 & 81 \\
24 & 1111100010 & 29 \\
25 & 1111100011 & 18 \\
\hline
\end{tabular}

Berdasarkan hasil dekompresi di atas didapati nilai desimal awal pixel citra sempel sebelum kompresi sebagai berikut 95, 97, 97, 53, 12, 99, 100, 93, 47, 14, 104, 104, 95, 40, 12, 105, 103, 89, 32, 14, 105, 102, 81, 29, 18. Nilai desimal pixel hasil dekompresi keseluruhan bisa dilihat akan gambar di bawah ini:

\begin{tabular}{|ccccc|}
\hline 95 & 97 & 97 & 53 & 12 \\
99 & 100 & 93 & 47 & 14 \\
104 & 104 & 95 & 40 & 12 \\
105 & 103 & 89 & 32 & 14 \\
105 & 102 & 81 & 29 & 18 \\
\hline
\end{tabular}

Gambar 11. Matriks Nilai Pixel Dekompresi

Berdasarkan pada gambar di atas hasil dekompresi mengembalikan seluruh nilai pixel sampel sebanyak 25 pixel tanpa adanya perubahan nilai dari proses sebelum kompresi, selanjutnya nilai pixel tersebut dirubah menjadi sebuah gambar sesuai file gambar asli.

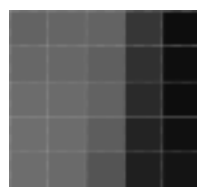

Gambar 12. Hasil Dekompresi Sempel File Gambar

Adapun proses dekompresi nilai $\mathrm{k}=1$ sampai dengan nilai $\mathrm{k}=5$ sama persis dengan proses dekompresi nilai $\mathrm{k}=0$.

\section{KESIMPULAN}

Berdasarkan hasil analisa yang telah dilakukan, maka penulis mengambil kesimpulan sebagai berikut :

1. Berdasarkan prosedur kompresi dengan menggunakan algoritma Subexponential Code telah berhasil melakukan proses kompresi file gambar, yang menggunakan sempel berekstensi *.bmp sehingga aplikasi yang diharapkan dapat berjalan sesuai dengan teknik kompresi.

2. Berdasarkan penelitian ini yang telah menggunakan algoritma Subexponential Code, telah membuktikan file gambar yang semulanya memiliki ukuran besar dapat di kompresi menjadi ukuran kecil, dan akan memberikan manfaat ruang memori yang lebih sedikit.

\section{REFERENCES}

[1] K. Mahesa, "Rancang Bangun Aplikasi Kompresi Dan Dekompresi Pada Citra Digital Menggunakan Metode Huffman,” vol. 12, no. 1, pp. 997-1012, 2017.

[2] L. Marlina, A. Putera, U. Siahaan, H. Kurniawan, and I. Sulistianingsih, "Data Compression Using Elias Delta Code,” Int. J. Recent Trends Eng. Res., vol. 3, no. 8, pp. 210-217, 2017.

[3] J. Enterprise, Rahasia Manajemen File. 2013.

[4] E. S. Mulyanta, Dari Teori Hingga Praktik : Pengolahan Digital Image dengan Photoshop CS2. .

[5] S. S. M. K. Dr.pulung Nurtantio Andono, S.T, M.Kom, T.sutojo, Konsep Pengolahan Citra Digital. Yogyakarta, 2015.

[6] Darma Putra, Pengolahan Citra Digital. Yogyakarta, 2010.

[7] L. Li and K. Chakrabarty, "On using exponential-golomb codes and subexponential codes for system-on-a-chip test data compression,” J. Electron. Test. Theory Appl., vol. 20, no. 6, pp. 667-670, 2004.

[8] D. Salomon, Data compression, vol. 3rd Editio. 2004.

[9] C. Shannon and F. Metode, "ALGORITMA SHANNON-FANO,” 2012. 